\title{
THE EFFECTIVENESS OF USING WHATSAPP AS A MEDIA IN ONLINE LEARNING AT GRADE 5 SD N 1 KARANGNONGKO JEPARA
}

\author{
Aida Dwi Fitria ${ }^{1}$, Nur Fajrie², Mohammad Syafruddin Kuryanto ${ }^{3}$ \\ 1,2,3 Universitas Muria Kudus, Indonesia \\ 1201733008@std.umk.ac.id, ${ }^{2}$ nur.fajrie@umk.ac.id, ${ }^{3}$ syafruddin.kuryanto@umk.ac.id
}

\begin{abstract}
Online learning has been carried out at SD N 1 Karangnongko Jepara due to the corona virus outbreak. As a result, learning at elementary schools was transferred online with the help of WhatsApp media. This study aimed to analyze the effectiveness of online learning through WhatsApp media. This study used a phenomenological qualitative research approach. The results showed that online learning using WhatsApp media tended to be less effective. This was influenced by several factors such as the difficulty of the internet signal and the ability of students who were not able to fully master WhatsApp application. Thus, an evaluation with related parties was required in order to create effective online learning.
\end{abstract}

Keywords: study, online, whatsapp

\section{EFEKTIVITAS PENGGUNAAN WHATSAPP SEBAGAI MEDIA DALAM PEMBELAJARAN DARING DI KELAS 5 SD N 1 KARANGNONGKO JEPARA}

\begin{abstract}
ABSTRAK
Pembelajaran daring dilaksanakan di SD N 1 Karangnongko Jepara. Hal ini disebabkan karena adanya wabah virus corona. Maka, pembelajaran di sekolah dasar dialihkan secara daring berbantuan media WhatsApp. Penelitian ini bertujuan untuk menganalisis efektifitas pembelajaran daring melalui media WhatsApp. Penelitian ini menggunakan pendekatan penelitian kualitatif fenomenologi. Hasilnya menunjukkan bahwa pembelajaran daring menggunakan media WhatsApp cenderung kurang efektif. Hal ini dipengaruhi dengan adanya beberapa faktor seperti susahnya sinyal internet dan kemampuan siswa yang belum dapat menguasai penuh tentang aplikasi WhatsApp. Perlu adanya evaluasi dengan pihak-pihak yang terkait untuk menciptakan pembelajaran daring yang efektif.
\end{abstract}

Kata Kunci: belajar, daring, whatsapp

\begin{tabular}{|c|c|c|}
\hline Submitted & Accepted & Published \\
\hline 12 Mei 2021 & 09 Agustus 2021 & 14 September 2021 \\
\hline
\end{tabular}

\begin{tabular}{|l|c|r|r|}
\hline Citation & $:$ & $\begin{array}{r}\text { Fitria, A. D., Fajrie N., \& Kuryanto, M.S . (2021). The Effectiveness of Using Whatsapp as A Media in Online Learning } \\
\text { at Grade 5 SD N 1 Karangnongko Jepara. Jurnal PAJAR (Pendidikan dan Pengajaran), 5(5), 1244-1251. DOI : } \\
\text { http://dx.doi.org/10.33578/pjr.v5i5.8439. }\end{array}$ \\
\hline
\end{tabular}

\section{PENDAHULUAN}

Belajar dan pembelajaran merupakan faktor penting dalam keberlangsungan pendidikan di Indonesia. Dengan adanya wabah virus corona atau yang biasa disebut Covid-19 semua sekolah yang berada di Indonesia diberlakukan metode pembelajaran yang awalnya metode pembelajaran tatap muka diganti dengan metode pembelajaran dalam jaringan atau disebut juga pembelajaran daring. Guru harus merancang cara atau metode agar pembelajaran dapat berjalan secara efektif, karena peran guru di dalam pembelajaran adalah sebagai proses pengelola pembelajaran.
Pembalajaran daring merupakan model pembelajaran yang tidak mengharuskan adanya tatap muka secara langsung, namun proses pembelajarannya tetap berjalan. Karena pembelajaran daring mempunyai keterbatasan ruang dan waktu. Jadi, proses pembelajaran dapat dilaksanakan secara fleksibel, artinya dapat dilaksanakan dimana saja dan kapan saja (Sofyana \& Rozaq, 2019).Selajan dengan pendapat (Khusniyah \& Hakim, 2019) bahwa teknologi komunikasi sebagai sarana penting yang dapat 
digunakan untuk pelaksanaan proses pembelajaran.

Akhir-akhir ini, kemajuan teknologi, budaya dan seni memudahkan manusia dalam beraktivitas. Misalnya, hadirnya perkembangan teknologi digital sangat bermanfaat bagi masyarakat. Dalam bidang pendidikan menggunakan teknologi digital yang dapat digunakan sarana dalam pembelajaran. Penggunaan teknologi informasi seperti internet sudah memiliki berbagai aplikasi, yakni sosial media. Hampir semua kegiatan pembelajaran dalam berkomunikasi dibantu oleh smartphone mulai dari mengirim pesan, menelpon sampai dengan hal-hal yang lain, seperti chatting. Dengan hadirnya smartphone aplikasi pengiriman pesan banyak bermunculan. Aplikasi tersebutmemiliki berbagai macam fitur menarik yang bertujuan untuk menarik penggunanya. (Astini, 2020) menyatakan bahwa teknologi informasi dapat dimanfaatkan untuk membantu dalam berlangsungnya proses pembelajaran ditengan pandemi covid-19. Pendidik dapat melakukan beberapa inovasi pembelajaran agar proses pembelajaran berlangsung dengan optimal adalah dengan memanfaatkan media pembelajaran online seperti media sosial atau aplikasi-aplikasi pembelajaran online yang lain (Atsani, 2020). Sistem pembelajaran daring yang umum digunakan guru adalah dengan menggunakan aplikasi WhatsApp (WA) karena dianggap lebih mudah diakses oleh pendidik dan peserta didik. Guru membuat grup kelas untuk mengirimkan tugas dan materi melalui grup tersebut. (Afifah et al., 2019) menyatakan bahwa WhatsApp adalah salah satu media sosial yang memiliki kategori chatting yang memungkinkan para pengguna untuk mengirim informasi atau pesan secara pribadi atau umum yakni dalam suatu grup dengan memiliki berbagai fitur yang lebih user-friendly sehingga mudah diakses oleh semua kalangan dari yang muda hingga tua.

Sebagai media sosial dalam bidang pendidikan, WhatsApp semakin bertambah tahun dengan meningkatnya kebutuhan pendidik dan peserta didik untuk saling berkomunikasi dengan seseorang atau kelompok orang. Aplikasi WhatsApp dapat diunduh dengan mudah melalui $\begin{array}{lrrr}\text { playstore. } & \text { Penggunaan } & \text { aplikasi } & \text { WhatsApp } \\ \text { memerlukan } & \text { koneksi } & \text { internet } & \text { dalan }\end{array}$ pengaksesannya yang memungkinkan pendidik dan peserta didik saling mengirim pesan, gambar dan video. Seperti yang dikatakan oleh (Afnibar \& Fajhriani, 2020) WhatsApp Group merupakan sebuah ruang kelas virtual yang memiliki fasilitas bagi setiap pengguna untuk berkomunikasi, berdiskusi dalam penyampaian materi atau penyampaian informasi yang lainnya. Jadi, dengan menggunakan WhatsApp group akan mempermudah para pengguna untuk menyampaikan pesan dengan cepat, seperti pesan tentang materi pembelajaran, jadwal ujian, atau pesan yang lainnya.

Pembelajaran daring menggunakan WhatsApp tidak semua pembelajaran berjalan dengan sempurna. Ada beberapa hambatan atau faktor yang dapat mempengaruhi dalam pembelajaran daring. Seperti Ketersediaan gawai dapat menjadikan faktor utama dalam pembelajaran daring. Tidak semua peserta didik berasal dari keluarga yang mampu. Hasil penelitian (Daheri et al., 2020) yang memperoleh data bahwa latar belakang orang tua, kurangnya penjelasan guru yang komprehensif dan sederhana serta susahnya signal dapat menjadi faktor utama dalam pembelajaran daring. Sehingga dengan penggunaan media WhatsApp dalam pembelajaran daring menjadi kurang efektif. Sejalan dengan pendapat (Kartika et al., 2021) yang mengungkapkan bahwa perasaan jenuh siswa menjadi kendala siswa dalam pmbelajaran daring. Hal ini karena siswa tidak dapat bertemu dengan temannya,dan tidak bisa menguasai materi secara mendalam karena siswa belajar hanya membaca dan menyimak materi yang bersumber dari internet. Selain itu guru juga merasakan bahwa dalam pembelajaran daring kurang maksimal dalam penyampaian materi serta melihat perkembangan siswa untuk menguasai materi menjadi sulit.

Penelitian terdahulu yang telah meneliti tentang pembelajaran daring dengan menggunakan aplikasi WhatsApp diantaranya adalah Pertama, (Daheri et al., 2020) yang meneliti tentang efektivitas WhatsApp sebagai media belajar daring. Kesimpulan akhir dari penelitian 
ini adalah penggunaan WhatsApp sebagai media belajar kurang efektif untuk mencapai tujuan. Kedua, penelitian (Prajana, 2017) membahas mengenai pemanfaatan aplikasi WhatsApp sebagai media pembelajaran e-learning. Kesimpulannya adalah bahwa aplikasi WhatsApp dapat diterpkan sebagai media e-learning. Ketiga, penelitian Jumiatmoko (Jumiatmoko, 2016) diperoleh data bahwa WhatsApp group dapat dijadikan inovasi dalam pembelajaran daring bagi sekelompok peserta didik, guru ataupun dosen.

Dari beberapa uraian tersebut, penelitian berikut ini akan membahas mengenai efektivitas efektivitas penggunaan WhatsApp sebagai media dalam pembelajaran daring di sekolah dasar. Tujuannya adalah untuk menganalisis efektifitas pembelajaran daring melalui media WhatsApp serta apa saja kelebihan dan kekurangan dari pembelajaran WhatsApp di SD N 1 Karangnongko

\section{KAJIAN TEORETIS}

Pembelajaran merupakan proses untuk membantu siswa agar dapat belajar dengan baik. Tetapi dalam implementasinya, kata pembelajaran sering diidentikkan dengan kata mengajar (Susanto, 2013). Jadi, istilah pembelajaran adalah ringkasan dari kata belajar dan mengajar. Degan kata lain, pembelajaran adalah bentuk sederhana dari kata belajar dan mengajar, proses belajar dan mengajar, atau kegiatan belajar mengajar.

(Syarifudin, 2020) mengatakan bahwa pembelajaran daring yaitu pembelajaran dalam jaringan dan dapat dikatakan sebagai pembelajaran jarak jauh. Pada era berkembangnya teknologi, pembelajaran dapat dilakukan dalam betuk virtual. Melalui pembelajaran virtual atau pembelajaran daring ini, proses belajar mengajar tidak terbatas oleh ruang dan waktu. Sehingga dalam pelaksanaannya bersifat fleksibel. Komunikasi antara guru dengan siswa terjadi kapanpun dan dimanapun. Pembelajaran daring dapat menjadikan siswa lebih aktif karena siswa dapat menemukan ilmu pengetahuan sendiri. Pembelajaran daring adalah pembelajaran tanpa adanya tatap muka secara langsung antara peserta didik dengan pendidik, tetapi dilakukan secara online. Sistem pembelajaran daring adalah implementasi dari pendidikan dengan jarak jauh yang dilakukan secara online. Pembelajaran daring bukan menjadi sesuatu hal baru, sudah terdapat teori-teori pendidikan dan penelitian yang berkaitan dengan pembelajaran jarak jauh sehingga seharusnya pembelajaran secara daring bukan sebuah proses digitalisasi bahan ajar, yaitu mengubah bahan ajar menjadi bahan bacaan secara digital.

(Jumiatmoko, 2016) juga mengatakan bahwa WhatsApp Messenger atau yang biasa disebut WA adalah teknologi Instan Messaging seperti sms dengan berbantuan jaringan internet berfitur pendukung yang lebih menarik. Adapun kelebihan dan kelemahan ketika penggunaan media WhatsApp dalam pembelajaran. Menurut (Pustikayasa, 2019) sebagai media, WhatsApp mempunyai kelebihan yaitu (1) Adanya group WhatsApp guru dengan siswa dapat berdiskusi lebih rileks tidak terpusat pada pendidik seperti pembelajaran di ruang kelas, yang dapat menimbulkan siswa malu dan takut salah ketika tanya jawab, (2) Guru dapat berkreasi dalam memberikan materi atau tugas kepada siswa, (3) siswa dapat mengirimkan tugas, baik berupa komentar, gambar, video, atau dokumen lainnya yang berhubungan dengan pembelajaran, (4) lebih ramah lingkungan dengan diberlakukannya metode pembelajaran menggunakan WhatsApp karena tidak menggunakan hardcopy, seperti cetakan kertas dan lain sebagainya, dan (5) WhatsApp dijadikan solusi bagi guru untuk mengirimkan tugas tambahan sebagai bahan pembelajaran diluar kelas. Adapun kekurangannya adalah sebagai berikut (1) Untuk mendapatkan informasi secara real, guru dn siswa harus terhubung dengan layanan internet, (2) Komunikasi menggunakan video, gambar dan file yang ukurannya besar dapat berpengaruh pada biaya penggunaan data, dan (3) diskusi dapat keluar dari konteks pembelajaran, karena tidak ada aturan jelas oleh admin grup.

Sejalan dengan pendapat (Ariza Rusni \& Elysa Evawani Lubis, 2017) kelebihan WhatsApp diantaranya adalah (1) tanpa memerlukan biaya untuk memasang aplikasi WhatsApp di smartphone, (2) dapat berkomunikasi dengan lebih dari 50 orang dalam sebuah group WhatsApp, (3) Penggunaan data kecil dibandingkan dengan aplikasi yang lainnya. Adapun kekurangannya 
adalah (1) tidak ada pilihan untuk daftar keluar, (2) tidak harus menggunakan laptop atau komputer dalam mengakses aplikasi WhatsApp, hanya dengan menggunakan Smartphone media WhatsApp sudah dapat digunakan. Jadi WhatsApp memiliki banyak fitur seperti chatting, video call, panggilan telepon, dan lain-lain yang memudahkan pengguna untuk bertukar pesan.

\section{METODE PENELITIAN}

Metode yang digunakan dalam penelitian tentang efektivitas penggunaan WhatsApp sebagai media dalam pembelajaran daring adalah metode penelitian kualitatif. Hal ini bertujuan agar mendapatkan hasil penelitian yang alami tidak adanya rekayasa dalam proses penelitiannya. Metode penelitian ini digunakan untuk meneliti suatu kondisi yang alami, peneliti berperan sebagai instrument utama (Human Instrument) dalam penelitian. Dalam penelitian ini menggunakan pendekatan fenomenologi, karena peneliti menyesuaikan dengan penelitian yang dilaksanakan. (Creswell, 2015) mengungkapkan bahwa studi fenomenologi yaitu mendeskripsikan sebuah pemaknaan umum dari sejumlah individu terhadap beragam pengalaman hidup individu mengenai konsep atau fenomena. Teknik pengumpulan data menggunakan tiga teknik. Pertama, observasi dengan melakukan pengamatan terhadap proses pelaksanaan pembelajaran daring melalui media WhatsApp. Kedua, wawancara yang dilakukan kepada guru dan siswa kelas 5 SD N 1 Karangnongko. Ketiga, dokumentasi berupa tulisan atau gambar sebagai pelengkap dari observasi dan wawancara agar dapat dijadikan bukti yang signifikan bahwa peneliti telah melakukan penelitian. Instrumen penelitian menggunakan lembar observasi, pedoman wawancara dan ceklist dokumentasi. Data dalam penelitian ini ditampilkan dalam bentuk gambar dan dijelaskan secara deskriptif. Subjek yang ada pada penelitian ini adalah guru dan siswa kelas 5 SD N 1 Karangnongko, dan objek yang diteliti adalah pembelajaran daring melalui media WhatsApp. Ada tahapan studi fenomenologi yang dikemukakan oleh Creswell dalam (Hamzah, 2020) langkah-langkahnya yaitu: (1) menentukan masalah, (2) memilih paradigma penelitian, (3) pengumpulan data, dan (4) analisis data. Berdasarkan uraian diatas, dpat digambarkan berupa bagan untuk mendesain penelitian fenomenologi:

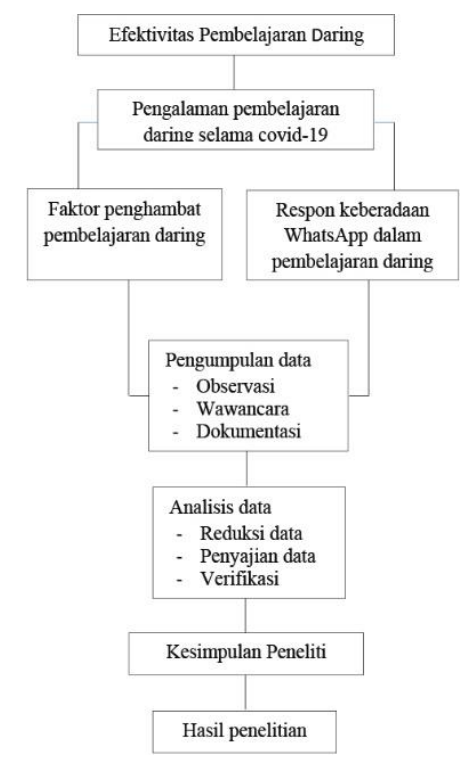

Gambar 1. Desain Penelitian 
Gambar diatas menunjukkan bahwa langkah awal untuk mendesain penelitian adalah menentukan masalah dalam penelitian fenomenologi adalah masalah yang dianggap paling baik untuk diteliti. Tipe yang baik adalah memahami pengalaman yang sama individu ataupun kelompok. Selanjutnya menentukan paradigm penelitian, yaitu pengalaman pembelajaran daring selama covid-19. Mengetahui bagaimana konstruksi siswa di dalam pembelajaran daring. Dari rumusan masalah tersebut dianalisis menggunakan observasi, wawancara, dan dokumentasi. Setelah dianalisis, data tersebut disimpulkan kemudian mendapat hasil penelitian.

\section{HASIL DAN PEMBAHASAN}

Penelitian ini dilaksanakan di SD N 1 Karangnongko Jepara. Waktu penelitian ini adalah pada bulan Maret 2021. Hasil penelitian ini diperoleh melalui wawancara kepada guru dan siswa kelas 5 SD N 1 Karangnongko. Selain itu, hasil penelitian ini diperoleh dari hasil observasi langsung tentang proses pembelajaran daring melalui media WhatsApp.

$\begin{array}{lllll}\text { Pembelajaran daring di } & \text { SD } & \mathrm{N} & 1\end{array}$ Karangnongko dilaksanakan mulai akhir bulan Maret 2020 sampai sekarang masih diberlakukan. Hal ini karena adanya wabah virus corona, maka pembelajaran yang awalnya di sekolah dapat bertatap muka dialihkan secara daring. Dengan demikian, guru dituntut untuk menggunakan internet dalam penyampaian materi dan tugas kepada siswa. Demikian dengan hasil penelitian (Putria et al., 2020) bahwa pelaksanaan pembelajaran daring memerlukan adanya data internet serta layanan internet yang stabil. (Handarini, dan Wulandari, 2020) juga mengungkapkan bahwa dibutuhkan sarana dan prasarana seperti komputer, gawai dan jaringan internet dalam proses pembelajaran daring. Maka sebelum menentukan diberlakukannya pembelajaran daring, pihak guru melakukan diskusi terlebih dahulu dengan semua pihak yang ada disekolah dan juga orang tua siswa. WhatsApp dijadikan sebagai media dalam pembalajaran daring di SD N 1 Karangnongko. Karena dianggap lebih mudah untuk mengakses baik dari kalangan guru maupun siswa.

Banyak faktor yang menghambat ketika dilaksanakan pembelajaran daring, yakni jaringan internet yang susah terkoneksi, gawai yang spesifikasinya rendah dapat menjadi hambatan ketika guru memberikan tugas atau siswa mengirimkan pesan gambar maupun video dengan kapasitas besar. Selain itu, guru harus kreatif dalam pembelajaran daring, mampu memberikan inovasi pembelajaran dalam media WhatsApp sehingga siswa tidak cepat bosan. Guru berusaha menyesuaikan kondisi wilayah, kemampuan siswa dan orang tua (Herliandry et al., 2020). Sebagai media pembelajaran, video call sebenarnya dapat menjadikan guru dan siswa dapat berkomunikasi dengan bertatap maya meskipun berbeda lokasi, seperti zoom, google classmeet dan lain sebagainya. Tetapi aplikasi seperti ini membutuhkan kuota yang sangat besar dan jaringan internet yang cukup stabil. Artinya, dalam wilayah pembelajaran daring tidak mudah, karena koneksi internet yang susah bahkan tidak ada (Atsani, 2020).

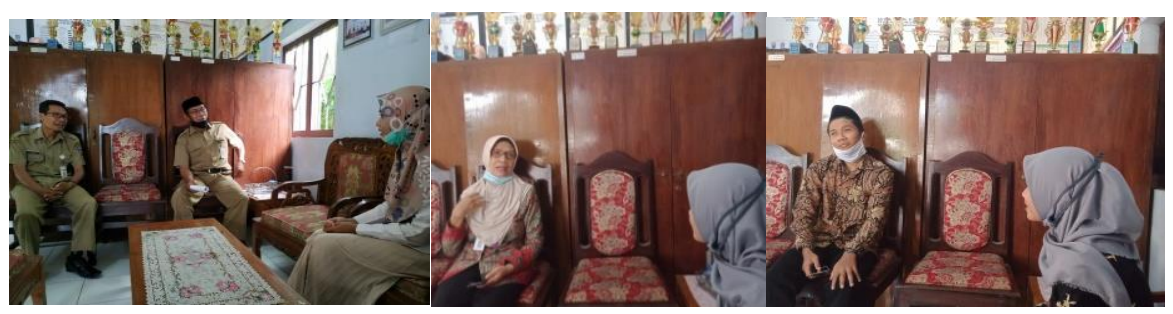

Gambar 1. Wawancara dan Observasi dengan Guru 
Hasil penelitian tentang efektifitas pembelajaran daring melalui media WhatsApp di SD N 1 Karangnongko mayoritas guru mengatakan bahwa pembelajaran menjadi kurang efektif. Hal ini adanya kendala ketika proses pelaksanaan pembelajaran daring, seperti siswa yang tidak mempunyai kuota internet harus pergi ke rumah tetangga untuk menyambungkan wifi agar tetap ikut melaksanakan pembelajaran. Selain itu ketika gawai yang dipegang oleh orang tua, dan orang tua tidak memberitahukan kepada anak akan adanya informasi atau pesan dari guru maka siswa tersebut ketinggalan materi pelajaran dan terlambat mengumpulkan tugas. Sebagian siswa tidak merespon ketika guru menyampaikan informasi. Berdasarkan observasi yang peniliti lakukan, siswa merasa bosan akan pembelajaran daring ini. Karena guru hanya memberikan materi yang penting saja, tidak semuanya diberikan kepada siswa. Selain itu, guru kurang kreatif ketika menyampaikan materi kepada siswa di group WhatsApp.

Berbeda dengan penelitian yang dilakukan oleh (Dewi, 2020) yang mengatakan bahwa pembelajaran daring di sekolah dasar terlaksana cukup baik. Meskipun guru dan orang tua bekerja sama dengan pelaksanaan pembelajaran daring, namun ketika lingkungan juga dijadikan sebagai media pembelajaran yang kurang memadai, maka efektifitas pembelajaran sangat diragukan. Hal ini dapat dilihat dari penelitian yang dilakukan oleh (Yanti et al., 2020) yang menyimpulkan bahwa memanfaatkan rumah belajar kemendikbud memberikan dampak positif terhadap proses pembelajaran di masa pandemic ini. Dengan demikian, aplikasi sebagai media pembelajaran daring memberikan dampak yang berbeda-beda, tergantung bagaimana penggunanya.

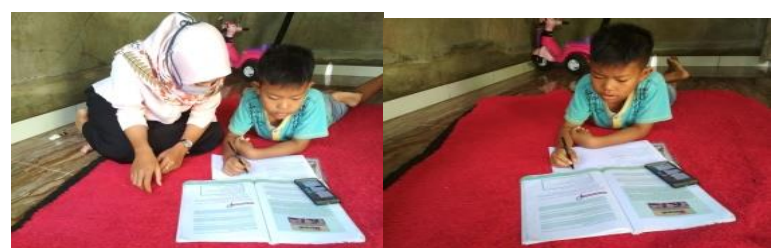

Gambar 2. Belajar di rumah Menggunakan WhatsApp

Hasil observasi dan wawancara yang dilakukan di SD N 1 Karangnongko Jepara, mengatakan bahwa ada kekurangan dan kelebihan menggunakan media WhatsApp. Kekurangan dalam media WhatsApp adalah penggunaan media WhatsApp harus membutuhkan kuota internet, kurangnya pengontrolan siswa, dan kemampuan kognitif siswa yang kurang terukur serta latar belakang keluarga siswa yang dapat mempengaruhi ketersediaan gawai untuk melakukan komunikasi dengan memanfaatkan media WhatsApp. Kelebihan media WhatsApp sebagai media pembelajaran yang digunakan di SD $\mathrm{N} 1$ Karangnongko adalah hanya dapat memberikan informasi melalui group WhatsApp dan memberikan serta mengirimkan tugas saja. Banyaknya kekurangan menggunakan media WhatsApp tersebut menjadikan pembelajaran daring menjadi kurang efektif.
Senada dengan pendapat (Anugrahana, 2020) dalam penelitiannya menyimpulkan bahwa hal yang menjadi hambatan dalam pembelajaran daring adalah orang tua harus meluangkan waktu untuk mendampingi siswa dalam belajar, sedangkan guru bergelut dengan teknologi dan dituntut harus belajar dan kreatif dalam melaksanakan pembelajaran daring.

\section{SIMPULAN DAN REKOMENDASI}

Penggunaan WhatsApp sebagai media pembelajaran daring dalam mencapai tujuan pembelajaran kurang efektif. Hal ini disebabkan adanya beberapa faktor seperti latar belakang keluarga siswa untuk ketersediaan gawai, susahnya mendapatkan signal, kemapuan kognitif siswa kurang terukur, dan kurangnya penjelasan guru terhadap materi pembelajaran. Perlu adanya 
evaluasi mengenai pembelajaran daring untuk membangun pembelajran daring yang efektif.

\section{DAFTAR PUSTAKA}

Afifah, N., Ningrum, P., Pramonojati, T. A., Sos, S., \& Ds, M. (2019). Pengaruh Penggunaan Aplikasi Whatsapp Terhadap Efektivitas Komunikasi Organisasi Di Lingkungan Pegawai Dinas Pariwisata Diy The Effect Of Whatsapp Use For The Effectiveness Of Organizational Communication In Yogyakarta Special Region Tourism Authority Sta. 6(1), 16801690.

Afnibar, A., \& Fajhriani, D. N. (2020). Pemanfaatan WhatsAPP sebagai Media Komunikasi Kegiatan Belajar ( Studi terhadap Mahasiswa UIN Imam Bonjol Padang ). Al-Munir: Jurnal Komunikasi Dan Penyiaran Islam, 11, 70-83. https://ejournal.uinib.ac.id/jurnal/index.ph p/almunir/article/download/1501/1122

Anugrahana, A. (2020). Hambatan, Solusi dan Harapan: Pembelajaran Daring Selama Masa Pandemi Covid-19 Oleh Guru Sekolah Dasar. Scholaria: Jurnal Pendidikan Dan Kebudayaan, 10(3), 282289.

https://doi.org/10.24246/j.js.2020.v10.i3.p 282-289

Ariza Rusni \& Elysa Evawani Lubis. (2017). Penggunaan Media Online WhatsApp dalam Aktivitas Komunitas One Day Onr Juz (ODOJ) dalam Meningkatkan Minat Tilawah Odojer di Kota Pekanbaru. 2, 115.

Astini, Sari, N. K. (2020). Pemanfaatan Teknologi Informasi dalam Pembelajaran Tingkat Sekolah Dasar pada Masa Pandemi Covid19. Jurnal Lembaga Penjaminan Mutu STKIP Agama Hindu Amlapura, 11(2), 13-25.

Atsani, K. L. G. M. Z. (2020). Transformasi Media Pembelajaran Pada Masa Pandemi Covid19. Al-Hikmah: Jurnal Studi Islam, 1, 8293.
Creswell, J. W. (2015). Penelitian Kualitatif \& Desain Riset (Memilih Diantara Lima Pendekatan) (Ke-3). Pustaka Belajar.

Daheri, M., Juliana, J., Deriwanto, D., \& Amda, A. D. (2020). Efektifitas WhatsApp sebagai Media Belajar Daring. Jurnal Basicedu, 4(4), 775-783. https://doi.org/10.31004/basicedu.v4i4.44 5

Dewi, W. A. F. (2020). Dampak COVID-19 terhadap Implementasi Pembelajaran Daring di Sekolah Dasar. Edukatif : Jurnal Ilmu Pendidikan, 2(1), 55-61. https://doi.org/10.31004/edukatif.v2i1.89

Hamzah, A. (2020). Metode Penelitian Fenomenologi (ke-1). CV.Literasi Nusantara Abadi.

Handarini, O.I., Wulandari, S. S. (2020). Pembelajaran Daring Sebagai Upaya Study From Home (SFH) Selama Pandemi Covid 19. Jurnal Pendidikan Administrasi Perkantoran (JPAP), 8, 496-503.

Herliandry, L. D., Nurhasanah, N., Suban, M. E., \& Kuswanto, H. (2020). Pembelajaran Pada Masa Pandemi Covid-19. JTP Jurnal Teknologi Pendidikan, 22(1), 6570.

https://doi.org/10.21009/jtp.v22i1.15286

Jumiatmoko, M. (2016). Whatsapp Messenger Dalam Tinjauan Manfaat Dan Adab. Wahana Akademika: Jurnal Studi Islam Dan Sosial, 3(1), 51. https://doi.org/10.21580/wa.v3i1.872

Kartika, M., Ismaya, E. A., \& Ahsin, M. N. (2021). Analisis Pembelajaran Daring di SD 2 Tenggeles Mejobo Kudus pada Masa Pandemi Covid-19. Lectura: Jurnal Pendidikan, 12, 41-56.

Khusniyah, N. L., \& Hakim, L. (2019). Efektivitas Pembelajaran Berbasis Daring: Sebuah Bukti Pada Pembelajaran Bahasa Inggris. Jurnal Tatsqif, 17(1), 19-33. https://doi.org/10.20414/jtq.v17i1.667

Prajana, A. (2017). Pemanfaatan Aplikasi Whatsapp Untuk Media Pembelajaran Dalam Lingkungan Uin Ar-Raniry Banda Aceh. Cyberspace: Jurnal Pendidikan 
Teknologi Informasi, $1(2), \quad 122$. https://doi.org/10.22373/cs.v1i2.1980

Pustikayasa, I. M. (2019). Grup WhatsApp Sebagai Media Pembelajaran. Widya Genitri: Jurnal Ilmiah Pendidikan, Agama Dan Kebudayaan Hindu, 10(2), 53-62. https://doi.org/10.36417/widyagenitri.v10 i2.281

Putria, H., Maula, L. H., \& Uswatun, D. A. (2020). Analisis Proses Pembelajaran dalam Jaringan (DARING) Masa Pandemi Covid- 19 Pada Guru Sekolah Dasar. Jurnal Basicedu, 4(4), 861-870. https://doi.org/10.31004/basicedu.v4i4.46 0

Sofyana, L., \& Rozaq, A. (2019). Pembelajaran Daring Kombinasi Berbasis Whatsapp Pada Kelas Karyawan Prodi Teknik Informatika Universitas Pgri Madiun. Jurnal Nasional Pendidikan Teknik Informatika (JANAPATI), 8(1), 81. https://doi.org/10.23887/janapati.v8i1.172 04

Susanto, A. (2013). Teori Belajar dan Pembelajaran Di Sekolah Dasar. Prenada Media Group.

Syarifudin, A. S. (2020). Implementasi Pembelajaran Daring untuk Meningkatkan Mutu Pendidikan sebagai Dampak Diterapkannya Social Distancing. Metalingua: Jurnal Pendidikan Bahasa Dan Sastra Indonesia, 5.

Yanti, M. T., Kuntarto, E., \& Kurniawan, A. R. (2020). Pemanfaatan Portal Rumah Belajar Kemendikbud Sebagai Model Pembelajaran Daring Di Sekolah Dasar. Adi Widya Jurnal Pendidikan Dasar, 10(1), 61-68. 